\title{
Is Single-stage Microvascular Reconstruction for Facial Mucormycosis Safe?
}

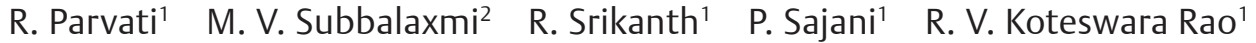 \\ ${ }^{1}$ Department of Plastic Surgery, NIMS, Hyderabad, India \\ 2Department of General Medicine, NIMS, Hyderabad, India \\ Address for correspondence R. V. Koteswara Rao, MCh (Plastic \\ Surgery), Department of Plastic Surgery, NIMS, Hyderabad, India \\ (e-mail: rayidi@hotmail.com).
}

Indian J Plast Surg 2021;54:130-137.

\begin{abstract}
Introduction This is a retrospective therapeutic series of eight cases of facial mucormycosis treated over a 15 -year period to determine the safety of simultaneous debridement and free-flap reconstruction in facial mucormycosis.

Methods Surgical debridement was done for three cases that presented acutely with systemic manifestations (group 1) and five cases that presented in the subacute phase without systemic manifestations (group 2). The debridement involved total maxillectomy with orbital exenteration in three cases, total maxillectomy with orbital preservation in two, and subtotal maxillectomy in three cases. A total of seven out of eight patients underwent reconstruction with free flap for defect closure; in one patient, only primary closure of mucosa was done.

Results The mean follow-up was 20.5 months. Two patients with acute disease, where reconstruction was done, died in the postop period (on the 27th and 6th day post reconstruction, respectively) due to continuing infection and septic shock. One of the three (group 1), who presented acutely and underwent debridement alone, survived. Four of five patients in group 2 underwent successful free-flap reconstruction. The patient with free-flap loss was salvaged with an extracorporeal radial forearm

\section{Keywords}

- facial mucormycosis

- mucormycosis

- maxillectomy

- reconstruction

- microvascular flap

- fungus flap. All except one patient had a soft-tissue free-flap reconstruction. Three of the six living patients reported for secondary surgery. The inability to achieve clear nonnecrotic surgical margins due to extensive disease was the reason for mortality in two patients in group 1 . There was no mortality in any of the group 2 patients, even when debridement and free-flap coverage was done simultaneously.

Conclusion Simultaneous debridement and free flap can be successfully implemented in select cases of facial mucormycosis
\end{abstract}

\section{Introduction}

Facial mucormycosis is an uncommon disease with a high mortality, which is due both to the presence of underlying diabetes mellitus or other immunosuppressive conditions and the vascular thrombosis consequent to the fungus, leading to large areas of tissue necrosis. ${ }^{1}$

The patient with such a facial infection comes within the province of several specialties-medical internist, clinical neurologist, ENT specialist, and neurosurgeon. ${ }^{2}$ What falls in
DOI https://doi.org/ $10.1055 / \mathrm{s}-0041-1731961$ ISSN 0970-0358
(C) 2021. Association of Plastic Surgeons of India.

This is an open access article published by Thieme under the terms of the Creative Commons Attribution-NonDerivative-NonCommercial-License, permitting copying and reproduction so long as the original work is given appropriate credit. Contents may not be used for commercial purposes, or adapted, remixed, transformed or built upon. (https://creativecommons.org/licenses/by-nc-nd/4.0/).

Thieme Medical and Scientific Publishers Pvt. Ltd. A-12, 2nd Floor, Sector 2, Noida-201301 UP, India 
the purview of the plastic surgeon is the need for surgical debridement for disease control and reconstruction of any defects that may ensue. A tissue diagnosis is mandatory to identify the fungus, using $\mathrm{KOH}$ smears or biopsy tissue blocks that are suitably stained. ${ }^{3}$

The mainstay of therapy is antifungal chemotherapy with either amphotericin B or the liposomal variant intravenously (IV). Surgical debridement plays an important role in disease control, either in a limited form, as sinus debridement or radical, as maxillectomies, depending on the extent of the disease. Surgery plays a role in preventing disease progression. In a study of 24 patients, 11 of 17 patients where surgical debridement was done survived and 7 where it was not done succumbed to the disease. ${ }^{4}$

Since this surgery is often mutilating, reliance is being placed on newer antifungal agents, singly or in combination (also to mitigate the frequent implications of renal function compromise), and immune modifying drugs to prevent large postsurgical defects that may need a complex reconstructive procedure. $^{5}$

Free flaps offer flexibility in providing vascularized coverage following radical excisions; the downside is the impact of complex, long-duration procedures in medically compromised individuals.

This retrospective series of eight cases, which underwent debridement and reconstruction using free flaps, aims to describe presentations commensurate with a favorable outcome.

\section{Materials and Methods}

The total number of patients were eight; seven males and one female, with a mean age of 35.3 years (range of 16 years to 51 years). Three of the eight patients presented with acute symptoms and systemic features of sepsis (group 1). Five of the patients presented with rhino-naso-orbital disease and no systemic manifestations (group 2).

Three in group 1 and two in Group 2 were referrals from medical and neurology units who were IV administered amphotericin. The other three in group 2 reported to the plastic surgery OPD following an ENT consultation elsewhere; they had partially completed antifungal chemotherapy before referral for disease sequelae (-Figs. 1-3).

Four of the patients reported orbital pain and swelling as the start of symptoms; four of them complained of facial swelling and redness and bloody nasal discharge.

All the patients were diabetics and two of them had their disease diagnosed during the evaluation for facial mucormycosis (the only female patient had gestation-induced diabetes). In addition, three of the patients were diagnosed with hypertension and were under treatment.

Four of the eight had diagnosis established with the help of $\mathrm{KOH}$ smears from the sinuses and four with tissue biopsy from necrotic patches.

All five patients, who were medical referrals, underwent both contrast-enhanced CT scan and MRI for assessing disease volume and response to chemotherapy. The three who presented to OPD with no clinical evidence of central

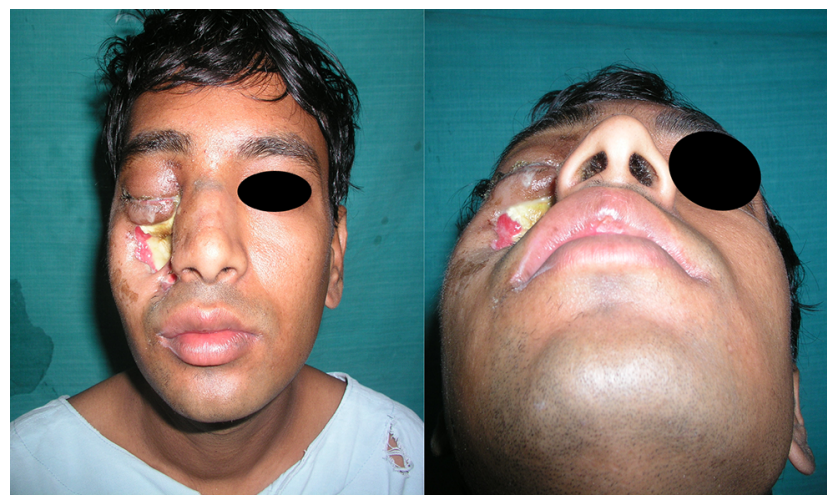

Fig. 1 Preop photos showing ulcer over the cheek and right orbital cellulitis.

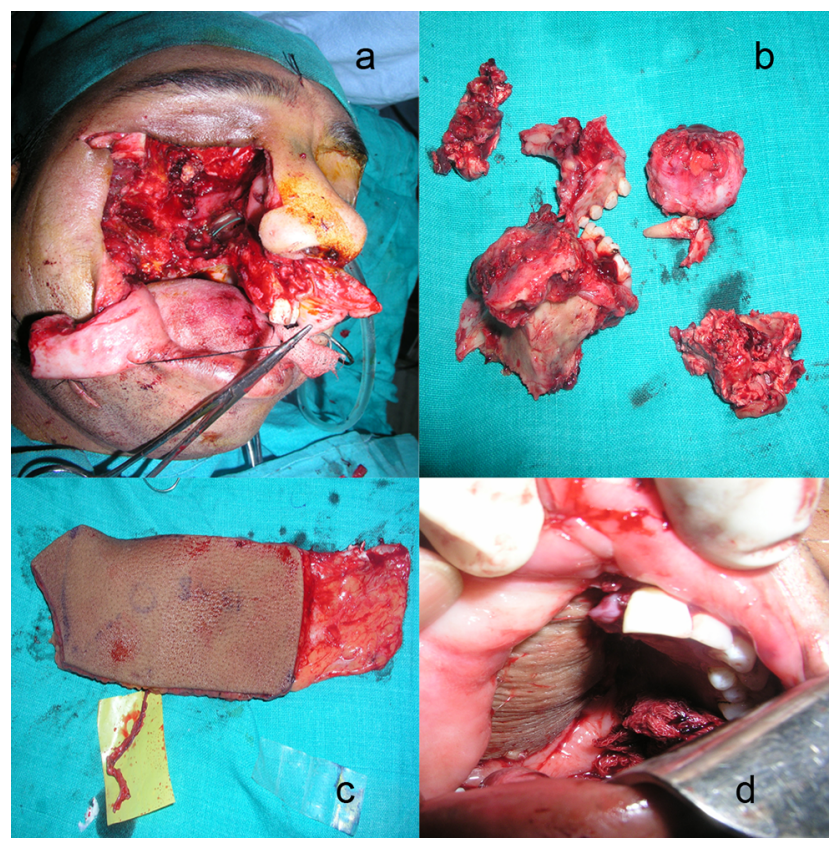

Fig. 2 (A) Defect following maxillectomy and exenteration; (B) excised necrotic tissues; (C) harvested anterolateral thigh (ALT) flap with fascial extension; (D) intraoral view of skin paddle inset over hemipalate.

nervous system (CNS) involvement or systemic complaints had contrast-enhanced CT scans as their workup.

Only two (group 2) had undergone limited open and endoscopic treatment for maxillary sinusitis elsewhere.

- Table 1shows the clinical details of the eight patients in chronological order of date of surgical intervention.

The surgical intervention was done within 4 weeks of the disease onset in three patients (group 1)-surgical debridement requested on account of less than optimal response to antifungals; the other five (group 2) were operated beyond 4 weeks of the onset of infection for debridement of necrotic tissues and reconstruction.

Two of the three in group 1 underwent a second-stage flap reconstruction 72 hours after the preliminary debridement ( - Figs. 4 and 5); in the third patient, debridement and primary closure of mucosa was done ( - Figs. 6-8). All the patients in group 2 had debridement and flap cover simultaneously. 


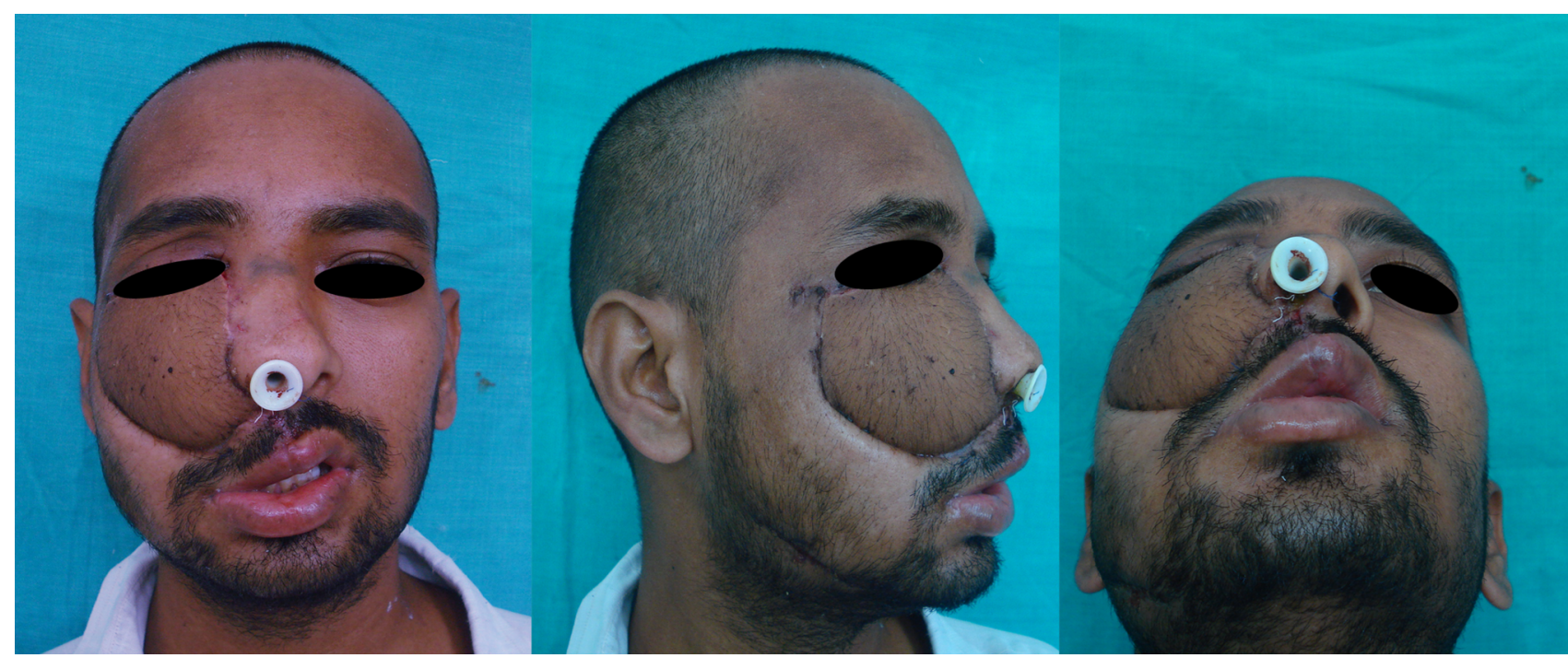

Fig. 3 Postop photos at 15 days with nasopharyngeal airway to prevent nasal stenosis.

Table 1 Demography and clinical presentation in individual cases

\begin{tabular}{|c|c|c|c|c|c|c|c|}
\hline $\begin{array}{l}\text { Case } \\
\text { No }\end{array}$ & $\begin{array}{l}\text { Date of } \\
\text { surgery }\end{array}$ & Age & Sex & $\begin{array}{l}\text { Predisposing } \\
\text { factor }\end{array}$ & $\begin{array}{l}\text { Diagnostic } \\
\text { history }\end{array}$ & Presentation & Initial treatment \\
\hline 1 & $8-2-2002$ & 48 & $\mathrm{M}$ & $\begin{array}{l}\text { Diabetes, } \\
\text { hypertension }\end{array}$ & Biopsy & $\begin{array}{l}\text { Acute presentation with } \\
\text { orbital cellulitis, orbital apex } \\
\text { syndrome and impending } \\
\text { CNS spread }\end{array}$ & $\begin{array}{l}\text { Amphotericin } 32 \text { days } \\
\text { before debridement }\end{array}$ \\
\hline 2 & $19-3-2003$ & 51 & M & Diabetes & $\mathrm{KOH}$ mount & $\begin{array}{l}\text { Acute presentation with } \\
\text { orbital cellulitis, ophthalmo- } \\
\text { plegia and impending CNS } \\
\text { spread }\end{array}$ & $\begin{array}{l}\text { Amphotericin } 24 \text { days } \\
\text { before debridement }\end{array}$ \\
\hline 3 & $\begin{array}{l}13-12- \\
2004\end{array}$ & 21 & $\mathrm{~F}$ & $\begin{array}{l}\text { Gestation-induced } \\
\text { diabetes }\end{array}$ & Biopsy & $\begin{array}{l}\text { Eschar over palate and ulcer } \\
\text { anterior wall maxilla; no } \\
\text { systemic manifestations }\end{array}$ & Amphotericin 21 days ${ }^{a}$ \\
\hline 4 & 14-9-2007 & 27 & M & $\begin{array}{l}\text { Newly diagnosed } \\
\text { diabetes }\end{array}$ & $\mathrm{KOH}$ mount & $\begin{array}{l}\text { Eschar over palate and } \\
\text { ulcer anterior wall maxilla; } \\
\text { orbital swelling; no systemic } \\
\text { manifestations }\end{array}$ & Amphotericin 14 days $^{a}$ \\
\hline 5 & $1-2-2008$ & 38 & $\mathrm{M}$ & $\begin{array}{l}\text { Diabetes, } \\
\text { hypertension }\end{array}$ & $\mathrm{KOH}$ mount & $\begin{array}{l}\text { Naso-oroantral fistula; no } \\
\text { vision in eye due to central } \\
\text { retinal artery thrombosis; } \\
\text { quiescent orbit tissues; no } \\
\text { systemic manifestations of } \\
\text { fungal infection }\end{array}$ & Amphotericin 37 days ${ }^{a}$ \\
\hline 6 & $11-2-2014$ & 32 & M & Diabetes & $\mathrm{KOH}$ mount & $\begin{array}{l}\text { Naso-oroantral fistula; no } \\
\text { systemic manifestations of } \\
\text { fungal infection }\end{array}$ & Amphotericin 40 days \\
\hline 7 & $5-6-2017$ & 16 & $\mathrm{M}$ & $\begin{array}{l}\text { Insulin-dependent } \\
\text { diabetes }\end{array}$ & Biopsy & $\begin{array}{l}\text { Eschar over anterior maxil- } \\
\text { lary wall and infraorbital rim; } \\
\text { no systemic manifestations } \\
\text { of fungal infection }\end{array}$ & Amphotericin 42 days \\
\hline 8 & $\begin{array}{l}24-11- \\
2017\end{array}$ & 50 & $\mathrm{M}$ & $\begin{array}{l}\text { Diabetes, } \\
\text { hypertension }\end{array}$ & Biopsy & $\begin{array}{l}\text { Acute presentation with } \\
\text { systemic symptoms and } \\
\text { necrotic patch over upper } \\
\text { central alveolus and palate; } \\
\text { systemic manifestations of } \\
\text { infection present }\end{array}$ & $\begin{array}{l}\text { Amphotericin } 28 \text { days } \\
\text { before debridement }\end{array}$ \\
\hline
\end{tabular}

Abbreviation: CNS, central nervous system.

${ }^{\text {a }}$ With a cumulative $3 \mathrm{gm}$ dose of amphotericin being therapeutic, only 5 of 8 patients completed the course before surgery. 


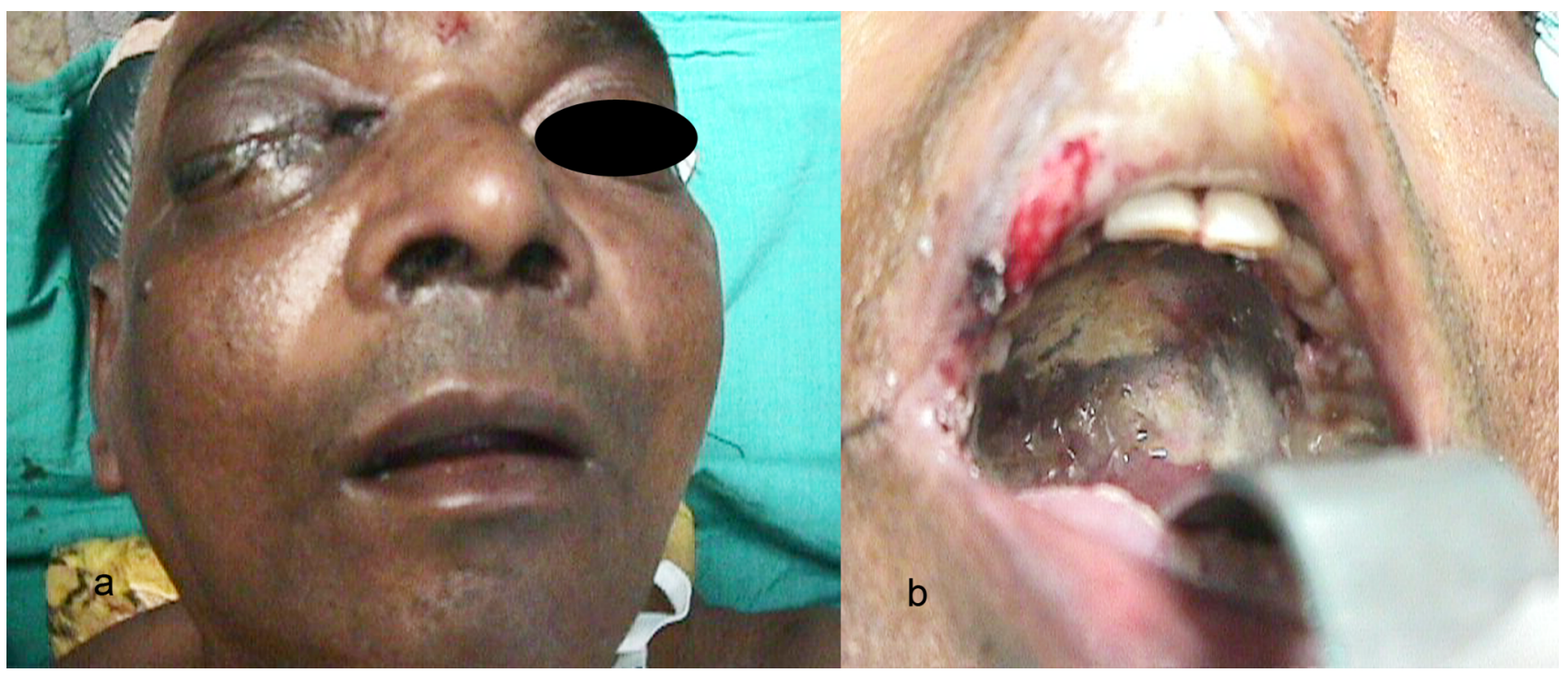

Fig. 4 Preop photos of acute presentation with orbital cellulitis and eschar over the palate.

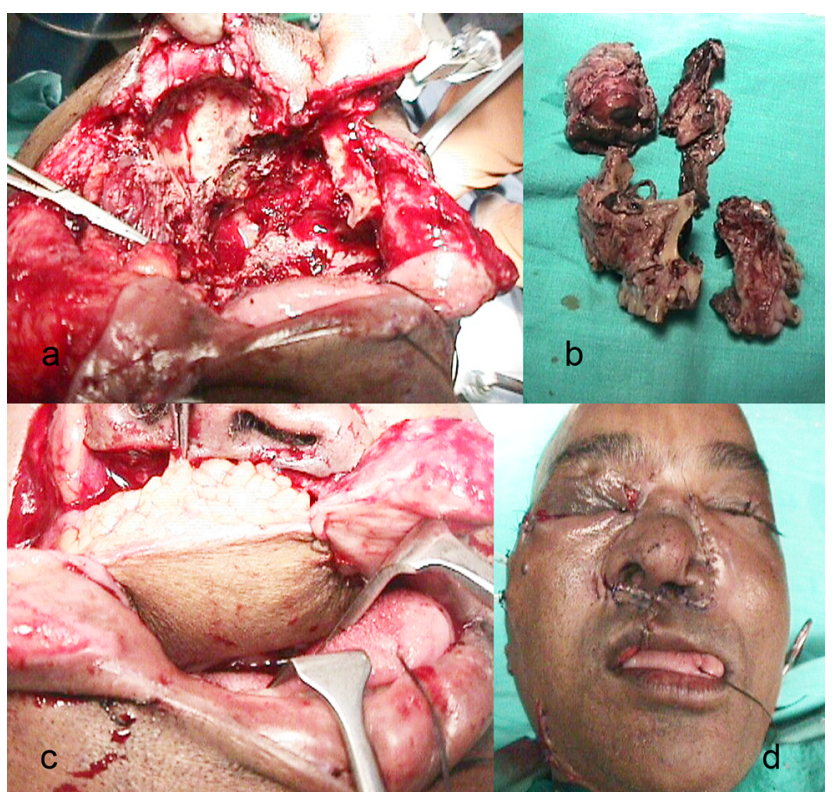

Fig. 5 (A) Maxillectomy exenteration defect; (B) debrided necrotic tissues; (C) skin paddle of gracilis used for palatal mucosa inset; (D) completed closure of Weber-Ferguson incision.

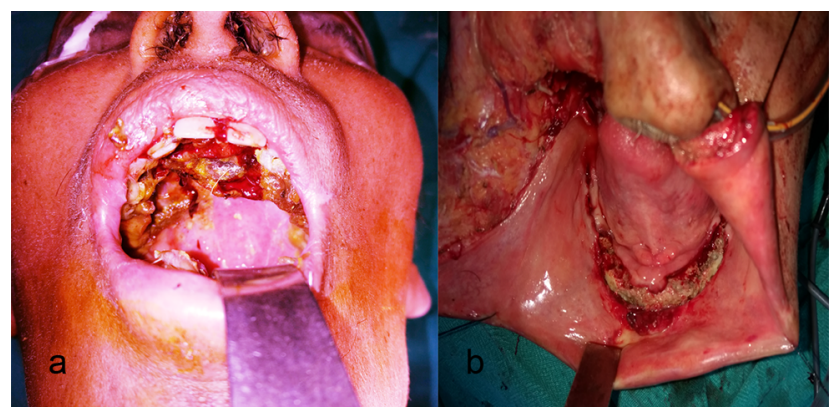

Fig. 6 (A) Necrotic eschar over the central maxillary alveolus and palate; (B) necrosis over the mandibular alveolus.

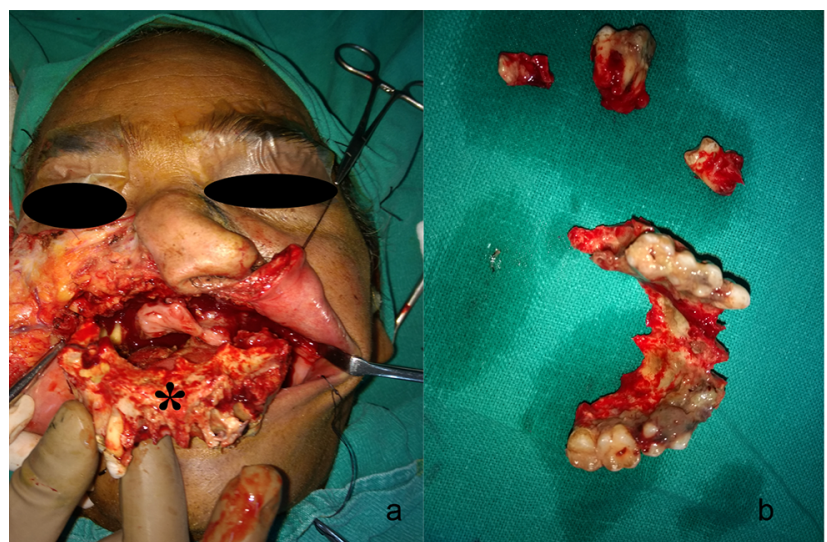

Fig. 7 (A) Asterisk shows necrotic upper alveolus and contiguous pyriform aperture; (B) necrotic bone specimen removed.

Four of eight patients had an elective tracheostomy for surgery, and the last patient in the series also underwent a feeding jejunostomy for purposes of feeding and nutrition.

Seven patients had free flap reconstruction-three gracilis flaps (two with skin paddle and one without), one fibular osteocutaneous flap, one rectus abdominis muscle flap with skin paddle (-Figs 9-11) and 2 anterolateral thigh (ALT) flaps. In the two cases (group 1) that presented acutely, the resection and reconstruction were staggered by 7 days on account of indeterminate excision margins and the need for redebridement.

The purpose of the flap was cavity filling, bulk restoration, and provision of nasal and oral lining in all except one case, where skeletal replacement of the alveolus was also done using the fibular osteocutaneous flap (-Figs. 12-14).

Gracilis flap, rectus abdominis flap, and one of two ALT flaps' donor sites were closed primarily; the other ATL flap, fibula flap, and the radial forearm flaps' donor site were split skin grafted. All donor sites healed uneventfully. 


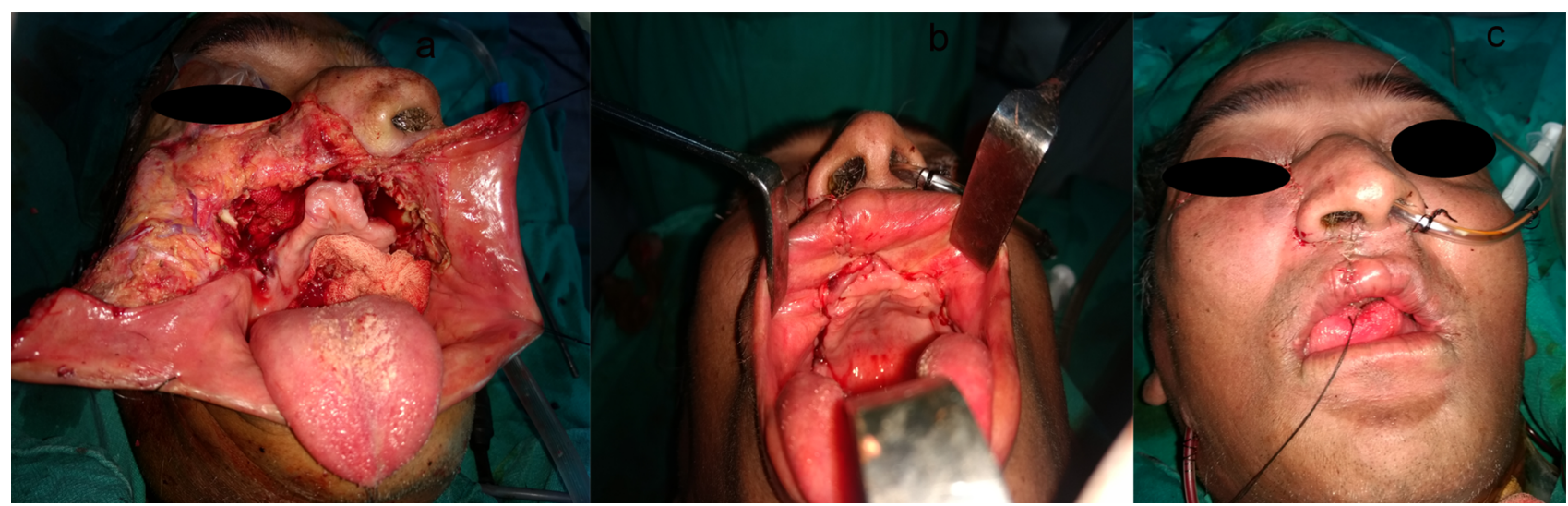

Fig. 8 Photos showing completion of debridement, mucosal closure primarily, and skin closure of bilateral Weber-Ferguson incisions.

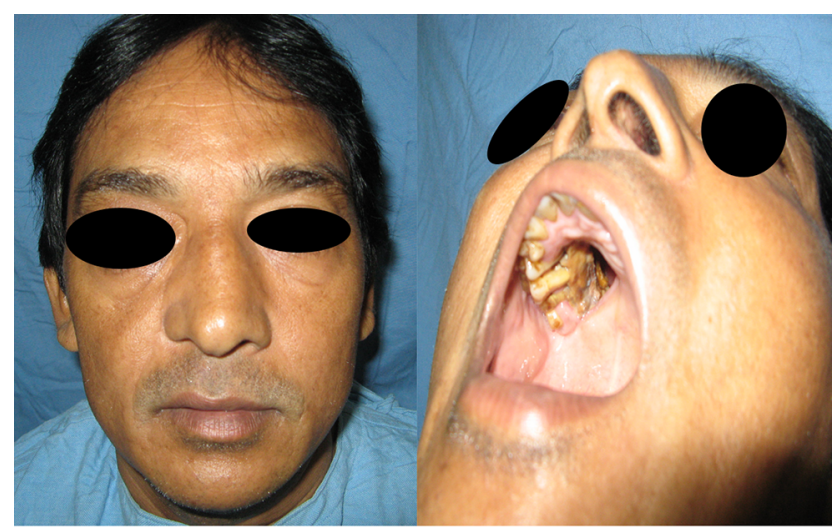

Fig. 9 Preop photos showing necrotic palatal bone and naso-oroantral fistula.

\section{Results}

Two of the three patients in group 1 died during their hospital course (on the 27th and 6th day postreconstruction, respectively) on account of septic shock. Both had extensive disease, CNS invasion (altered sensorium even while taking up for debridement), poor response to preop chemotherapy, and unclear margins during debridement. The free flaps were viable at the time till the mortality. The third patient in group 1, in spite of chemotherapy induced renal failure, poorly controlled diabetes and bronchopneumonia, survived. He had clear surgical margins macroscopically and did not undergo any reconstruction.

There were no deaths in group 2 cases; one ALT flap failed and was debrided after 72 hours. There was documented intraop hypotension that led to the arterial anastomosis being revised twice. The resulting wound was managed conservatively for the next 3 weeks, feeding being ensured through a nasogastric tube. At 3 weeks, a folded extracorporeal radial forearm flap was done (a second free flap being avoided for logistics of cost and patient wishes), which was detached after 23 days and complete flap inset given.

Only one of the seven patients had a fibula osteocutaneous flap done, with a view to recreate deficient upper central alveolus and permit future nasal reconstruction for necrosed pyriform aperture. The second patient with a near-similar defect (the last of this series) underwent excision and closure only, considering he would not have been fit for a microvascular procedure.

Three patients underwent secondary surgery in the form of skin paddle reduction, skin graft excision and closure and augmentation rhinoplasty.

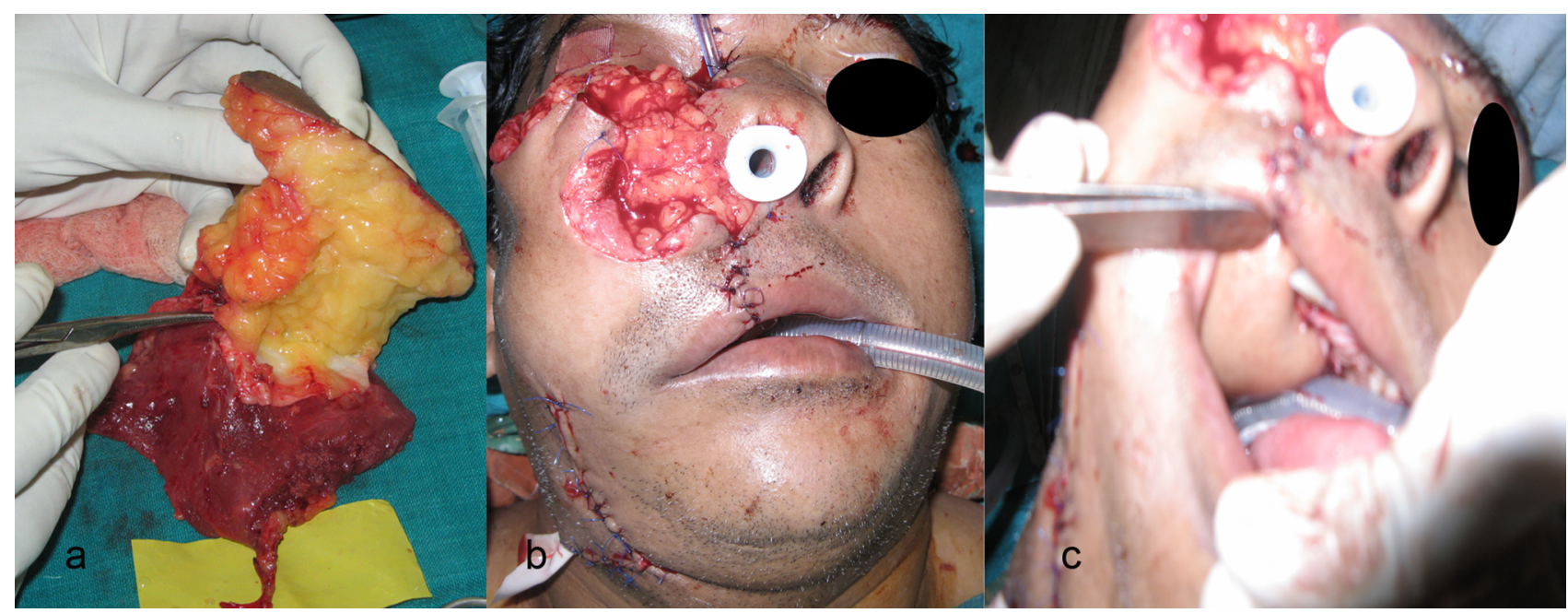

Fig. 10 (A) Harvested rectus abdominis flap with skin paddle; (B) inset flap prior to skin closure; (C) intraoral view of paddle inset on hemipalate. 


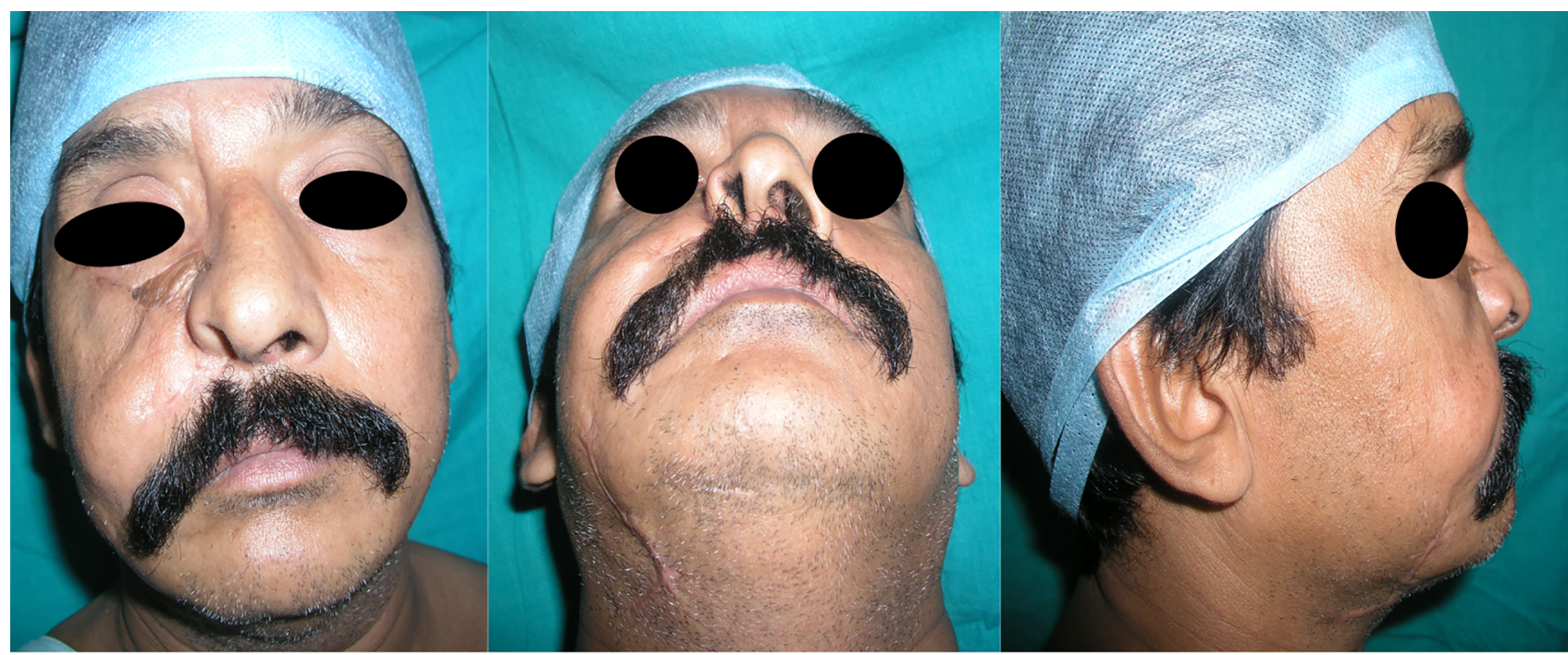

Fig. 11 Follow-up photos showing acceptable contour prior to secondary correction surgery.

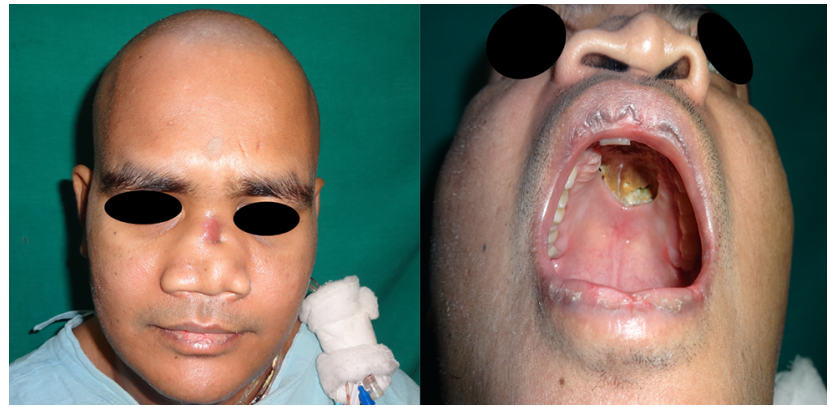

Fig. 12 Preop photos showing oronasal fistula, necrotic alveolus, and nasal dorsal collapse.

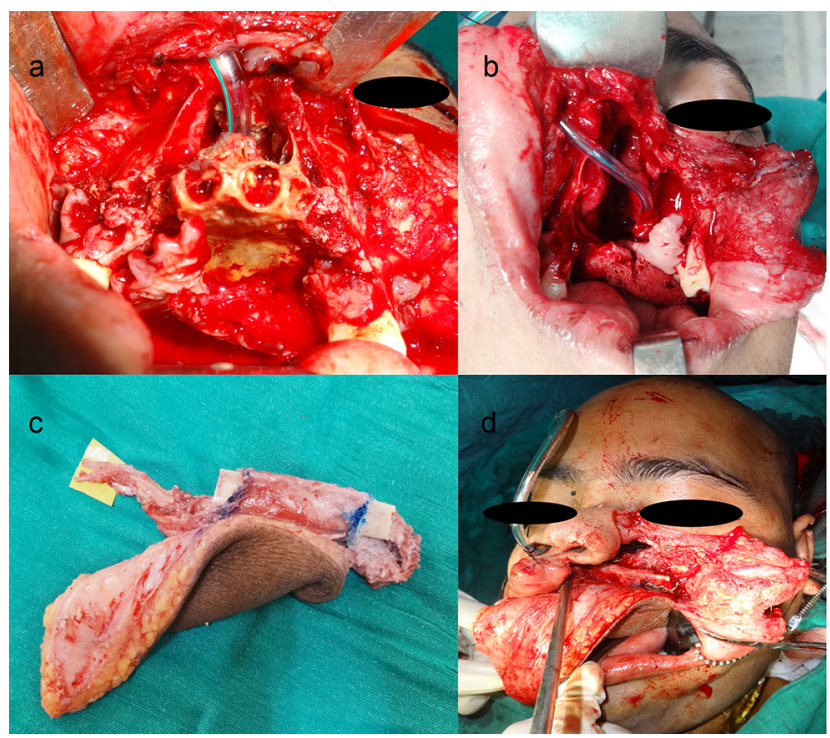

Fig. 13 (A) Necrotic segment of central upper alveolus and pyriform aperture; (B) postexcisional defect; (C) fibula flap with skin paddle with peroneal pedicle; (D) skin paddle inset for palatal mucosa.

One of the six living patients was lost to follow-up after the 15th postoperative at OPD; the follow-up period in the

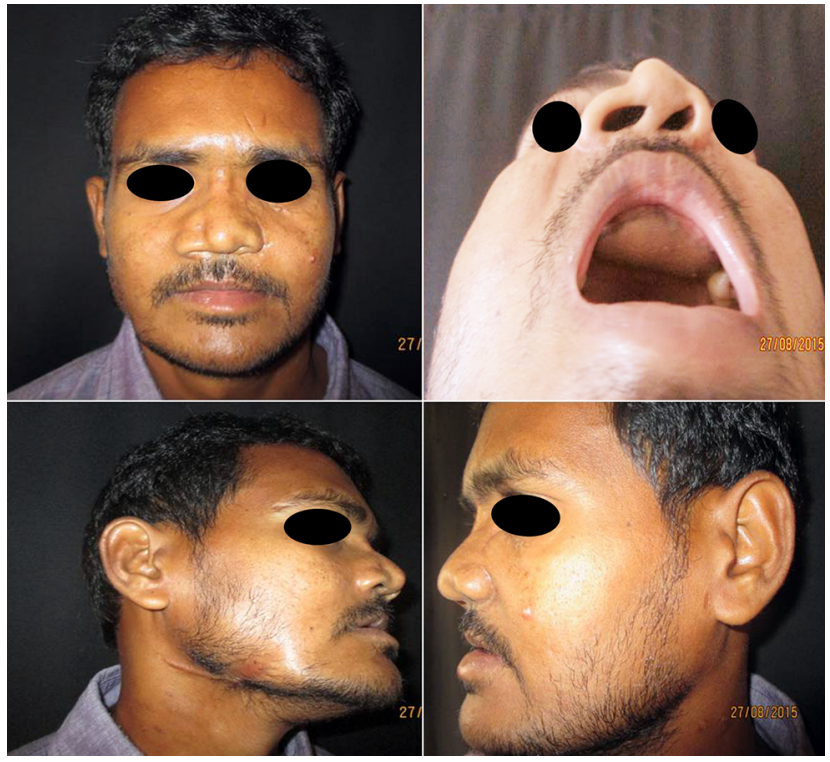

Fig. 14 Follow-up photos after fibula flap reconstruction and second stage iliac crest bone grafting for nasal dorsum.

other five living patients ranged from 7 months to 50 months (mean of 20.5 months).

- Table 2 shows the excision and reconstruction details of the eight patients in chronological order of date of surgical intervention.

\section{Discussion}

Our series of eight patients over the course of 15 years has shown that these patients present to us in two patterns: the acute presentation with facial and eye swelling, altered sensorium with eschar over the palate (usually referred by other medical specialties)-group 1 and group 2-with an ulcer or eschar over the palate, cheek with or without fistula, nasal discharge, and no systemic manifestations. There were three in group 1 and five in group 2. 
Table 2 Excisional defect and reconstructive method in individual cases

\begin{tabular}{|c|c|c|c|c|c|}
\hline $\begin{array}{l}\text { Case } \\
\text { No }\end{array}$ & Areas afflicted & $\begin{array}{l}\text { Excision and } \\
\text { defect }\end{array}$ & Reconstruction & $\begin{array}{l}\text { Recipient } \\
\text { pedicles }\end{array}$ & Remarks \\
\hline 1 & $\begin{array}{l}\text { Eye, ipsilateral maxilla } \\
\text { and palate }\end{array}$ & $\begin{array}{l}\text { Maxillectomy and } \\
\text { orbital exenteration }\end{array}$ & $\begin{array}{l}\text { Gracilis with skin } \\
\text { paddle }\end{array}$ & $\begin{array}{l}\text { Facial artery and } 1 \\
\text { venae comitantes }\end{array}$ & $\begin{array}{l}\text { Septic shock death 27th day } \\
\text { postreconstruction }\end{array}$ \\
\hline 2 & $\begin{array}{l}\text { Eye, ipsilateral maxilla } \\
\text { and palate }\end{array}$ & $\begin{array}{l}\text { Maxillectomy and } \\
\text { orbital exenteration }\end{array}$ & $\begin{array}{l}\text { Gracilis with skin } \\
\text { paddle }\end{array}$ & $\begin{array}{l}\text { Facial artery and } 1 \\
\text { venae comitantes }\end{array}$ & $\begin{array}{l}\text { Septic shock death 6th day } \\
\text { postreconstruction }\end{array}$ \\
\hline 3 & $\begin{array}{l}\text { Infraorbital rim and } \\
\text { anterolateral maxilla } \\
\text { full thickness cheek } \\
\text { defect ipsilateral hard } \\
\text { palate }\end{array}$ & $\begin{array}{l}\text { Maxillectomy and } \\
\text { orbital preservation }\end{array}$ & ALT flap & $\begin{array}{l}\text { Facial artery and } \\
\text { EJV }\end{array}$ & $\begin{array}{l}\text { Flap loss due to venous con- } \\
\text { gestion 3rd postop day; flap } \\
\text { debridement done; at } 3 \text { weeks } \\
\text { extracorporeal folded radial } \\
\text { forearm flap done. Detachment } \\
\text { and inset after } 23 \text { days } \\
\text { Follow-up } 10 \text { months }\end{array}$ \\
\hline 4 & $\begin{array}{l}\text { Anterolateral wall } \\
\text { maxilla, hard palate } \\
\text { and orbit }\end{array}$ & $\begin{array}{l}\text { Maxillectomy and } \\
\text { orbital exenteration }\end{array}$ & ALT flap & $\begin{array}{l}\text { Facial artery and } 1 \\
\text { venae comitantes }\end{array}$ & $\begin{array}{l}\text { Complete flap survival; ampho- } \\
\text { tericin for } 15 \text { days postop. Lost } \\
\text { to follow-up after that time. }\end{array}$ \\
\hline 5 & $\begin{array}{l}\text { Allergic rhinitis/lateral } \\
\text { rhinotomy and orona- } \\
\text { sal fistula } \\
\text { CRA thrombosis with } \\
\text { no vision }\end{array}$ & $\begin{array}{l}\text { Maxillectomy and } \\
\text { orbital preservation }\end{array}$ & $\begin{array}{l}\text { Rectus abdominis } \\
\text { myocutaneous flap }\end{array}$ & $\begin{array}{l}\text { Facial artery and } 2 \\
\text { venae comitantes }\end{array}$ & $\begin{array}{l}\text { Complete flap survival; one sec- } \\
\text { ondary skin paddle reduction } 4 \\
\text { months later; follow-up of } 22 \\
\text { months }\end{array}$ \\
\hline 6 & $\begin{array}{l}\text { Central portion } \\
\text { middle third of face; } \\
\text { nasal bones, maxillary } \\
\text { alveolus, oronasal } \\
\text { fistula }\end{array}$ & $\begin{array}{l}\text { Subtotal maxillec- } \\
\text { tomy a }\end{array}$ & $\begin{array}{l}\text { Fibula osteocutaneous } \\
\text { flap }\end{array}$ & $\begin{array}{l}\text { Facial artery and } 2 \\
\text { venae comitantes }\end{array}$ & $\begin{array}{l}\text { Complete flap survival; second- } \\
\text { ary skin paddle thinning and } \\
\text { augmentation rhinoplasty with } \\
\text { bone graft; follow-up for } 50 \\
\text { months }\end{array}$ \\
\hline 7 & $\begin{array}{l}\text { Superomedial maxilla } \\
\text { and orbital floor; } \\
\text { palate unaffected }\end{array}$ & $\begin{array}{l}\text { Subtotal maxillec- } \\
\text { tomy }{ }^{\mathrm{b}}\end{array}$ & Gracilis and skin graft & $\begin{array}{l}\text { Facial artery and } 1 \\
\text { venae comitantes }\end{array}$ & $\begin{array}{l}\text { Complete flap survival; partial } \\
\text { skin graft loss with secondary } \\
\text { healing; } 15 \text { months follow-up }\end{array}$ \\
\hline 8 & $\begin{array}{l}\text { Central upper maxilla, } \\
\text { mandibular alveolus, } \\
\text { lower third of the } \\
\text { nose }\end{array}$ & $\begin{array}{l}\text { Subtotal maxillec- } \\
\text { tomy }{ }^{c}\end{array}$ & No reconstruction done & - & 6 month follow up \\
\hline
\end{tabular}

Abbreviations: ALT, anterolateral thigh; CRA, central retinal artery; EJV, external jugular vein.

${ }^{a}$ Central upper alveolus, adjacent palate, lateral nasal walls and septum.

b Maxilla in superomedial portion and orbital rim and anterior orbital floor.

c Central upper alveolus, adjacent palate, lateral nasal walls and septum.

Jacob et al divided their patients into three groups: sinonasal disease only, sinonasal and orbital disease, and disease with CNS spread. Even in their second group, with no evidence of CNS spread, there were treatment failures, and death in seven out of nine patients in spite of debridement. They also pointed out that 5 patients with clinical evidence of orbital disease had normal CT scans. ${ }^{6}$

Clinical evaluation for orbital and CNS involvement is important, and since the group 2 patients in our series had no clinical evidence of CNS invasion and/or systemic manifestations, a contrast-enhanced CT scan was the mainstay investigation to rule out breach of the orbital floor, as this could change the extent of resection.

All the patients in group 1 were being managed by medical specialties, both CT scans and MRI were available to assess both disease burden and response to treatment.

The five patients in group 2 had conventional amphotericin IV administered over a duration that ranged from 2 weeks to 6 weeks; default from amphotericin (only in group 2) was usually on account of financial reasons. Two of the five also had tentative surgical procedures-one open and one endoscopic for treatment of symptoms attributed to a maxillary sinus locale for the fungal infection.
Literature shows a preference for delayed reconstruction after surgical debridement in most cases-13 of 16 cases, with an average time of delayed reconstruction of 16.7 weeks (range: 2-36 weeks). Only two authors (3/16) described early or immediate reconstruction. ${ }^{7}$

Adler in 2008 reported on a case of facial mucormycosis for which maxillectomy and orbital exenteration was followed by chimeric ALT flap, with death at 10 days on account of complications like dural leaks and progressive cerebellar infarcts; although, the margins of disease were negative. ${ }^{8}$

Metzen in 2012 reported two cases-in one, maxilla reconstruction done 27 days after the onset of disease, treated mainly by chemotherapy and then debridement with scapula bone flap with skin paddle; the patient survived. The other case where the debridement was done 24 hours after the diagnosis was established, death occurred even before reconstruction could be done. ${ }^{9}$

Early debridement and free flap cover seems to be associated with a high mortality, but this could be due to difference in the volume of disease and response to antifungal chemotherapy.

In four of five postmaxillectomy reconstructions done by Ashok et al, the free flaps were done for granulating defects 
after a preliminary debridement and not primarily; a philosophy to ensure no evidence of disease during a complex reconstruction. ${ }^{3}$

Palacios reported five free flaps, with four for skeletal disease-three immediate and one delayed with no mortality. One-cm margins specifically confirmed by rapid hyphal staining, using hematoxylin eosin staining, ensured a high rate of success. ${ }^{7}$ This seems to be the only true report of a primary free flap done during the time of debridement; there were no flap losses.

Augustine et al laid emphasis on the role of repeated aggressive debridement where the presentation is acute with rhino-naso-orbital disease. Two cases of pediatric mucormycosis of less than 4 years age, with staged debridement, antifungal therapy, and microvascular reconstruction with free fibular or iliac crest skin and bone flap; one patient survived and the other died of the underlying disease. ${ }^{10}$

Two of three patients in group 1 died in hospital following maxillectomy/orbital exenteration and reconstruction with gracilis myocutaneous flaps; extensive disease (probably consequent to poor chemotherapeutic response) and inability to get negative margins even after the second debridement led to the adverse outcome. Decision to reconstruct a "difficult to manage" defect can be mitigated by the use of good prosthetics when available. ${ }^{11}$

The third patient in group 1 survived, probably because debridement and primary closure of mucosa was sufficient to achieve wound healing; the decision "not to reconstruct" was a "no brainer" on account of the location of the defectthe central upper alveolus and contiguous pyriform aperture-a location easily amenable to primary mucosal closure. At follow-up, the feeding jejunostomy could be removed at 40 days and he is disease free and able to swallow fluids and blenderized foods. He is awaiting defect reconstruction with free bone flap.

The one flap loss in group 2 patients was theoretically avoidable and cannot be ascribed to the infection or the consequence of immediate reconstruction. She was salvaged with an extracorporeal radial forearm flap, although as an interval procedure (on account of logistic reasons and not medical).

Muscle flaps with skin paddle and skin flaps have been equally used and reflect individual preferences. Free flaps from the abdomen have also been used, as described by Silberstein and Odessey. ${ }^{12,13}$ Osteocutaneous flaps offer the option of future dental rehabilitation.

Palacios preferred ALT flaps over osteocutaneous flaps, especially when the orbit has been exenterated. ${ }^{7}$

In our series, although the nature of defect could have dictated the choice of an osteocutaneous flap in at least three cases in group 2, it was actually done in only one. Choosing a simpler soft-tissue flap over a complex osteocutaneous flap ensures patient safety beyond future aesthetic concerns.

\section{Conclusion}

The present experience of facial mucormycosis over a 15-year period helps in identifying two subsets of patients to decide on the safety of debridement, followed by an immediate reconstruction.

In patients who present with partially or completely sterilized disease with necrotic sequelae of mucormycosis, single-stage debridement and free-flap reconstruction can be safely offered.

Acute presentations where surgery is requested for disease control should not be subjected to any primary reconstruction, regardless of the complexity of the defect, to prevent mortality, especially so if negative margins cannot be assured.

\section{Funding \\ None. \\ Conflict of Interest \\ None declared.}

\section{References}

1 Bergstrom L, Hemenway WG, Barnhart RA. Rhinocerebral and otologic mucormycosis. Ann Otol Rhinol Laryngol 1970;79(1):70-81

2 Shand JM, Albrecht RM, Burnett HF II, Miyake A. Invasive fungal infection of the midfacial and orbital complex due to Scedosporium apiospermum and mucormycosis. J Oral Maxillofac Surg 2004;62(2):231-234

3 Srikanth V, Kumar P, Anantheswar YN, Sudarshan AB, Bhatt R. Cranio-facial mucormycosis-the plastic surgeon's perspective. Eur J Plast Surg 2019;43:1-8

4 Petrikkos G, Skiada A, Sambatakou H, et al. Mucormycosis: ten-year experience at a tertiary-care center in Greece. Eur J Clin Microbiol Infect Dis 2003;22(12):753-756

5 Spellberg B, Ibrahim AS. Recent advances in the treatment of mucormycosis. Curr Infect Dis Rep 2010;12(6):423-429

6 Nithyanandam S, Jacob MS, Battu RR, Thomas RK, Correa MA, D'Souza O. Rhino-orbito-cerebral mucormycosis. A retrospective analysis of clinical features and treatment outcomes. Indian J Ophthalmol 2003;51(3):231-236

7 Juarez J, Hanson V, Medina ER, Raúl MS. Reconstruction of head and neck mucormycosis: a literature review and own experience in immediate reconstruction. J Reconstr Microsurg Open 2019;04:e102-e102

8 Adler N, Seitz IA, Gottlieb LJ. Acute wound closure and reconstruction following head zygomycosis: presentation of two cases and review of literature. J Reconstr Microsurg 2008;24(7):507-513

9 Metzen D, Böhm H, Zimmermann M, Reuther T, Kübler AC, Müller-Richter UD. Mucormycosis of the head and neck. J Craniomaxillofac Surg 2012;40(8):e321-e327

10 Augustine HFM, White C, Bain J. Aggressive combined medical and surgical management of mucormycosis results in disease eradication in 2 pediatric patients. Plast Surg (Oakv 2017;25(3):211-217

11 Deshpande S, Bhat S, Sharma R, Singh S, Fernandes J. Prosthetic rehabilitation of face following naso-orbital mycosis. Indian J Plast Surg 2006;39(1):73-75

12 Silberstein E, Krieger Y, Rosenberg N, et al. Facial reconstruction of a mucormycosis survivor by free rectus abdominis muscle flap, tissue expansion, and ocular prosthesis. Ophthal Plast Reconstr Surg 2016;32(6):e131-e132

13 Odessey E, Cohn A, Beaman K, Schechter L. Invasive mucormycosis of the maxillary sinus: extensive destruction with an indolent presentation. Surg Infect (Larchmt 2008;9(1):91-98 